\title{
Communication
}

\section{Origanum vulgare ssp. hirtum Essential Oil as a Natural Intrinsic Hurdle against Common Spoilage and Pathogenic Microbes of Concern in Tomato Juice}

\author{
Gregoria Mitropoulou ${ }^{1}$, Antigoni Oreopoulou ${ }^{2}$, Eleni Papavassilopoulou ${ }^{2}$, Manolis Vamvakias ${ }^{2}$, \\ Panayiotis Panas ${ }^{3}$, Stavros Fragias ${ }^{4}$ and Yiannis Kourkoutas ${ }^{1, *(\mathbb{D})}$ \\ 1 Laboratory of Applied Microbiology and Biotechnology, Department of Molecular Biology \& Genetics, \\ Democritus University of Thrace, GR-68100 Alexandroupolis, Greece; gmitropo@mbg.duth.gr \\ 2 Vioryl, Chemical and Agricultural Industry, Research S.A., 28th km Athens-Lamia National R.D., \\ P.O. Box 149, GR-19014 Afidnes, Greece; antigoni@vioryl.gr (A.O.); papavassilopoulou@vioryl.gr (E.P.); \\ vamvakias@vioryl.gr (M.V.) \\ 3 QLCon, NEO Patron Athinon 57, GR-25018 Patras, Greece; panas@qlc.gr \\ 4 PAXMAN Ltd., Patras Industrial Zone, Ag. Stefanos, GR-25018 Patras, Greece; sf@paxman.gr \\ * Correspondence: ikourkou@mbg.duth.gr; Tel.: +30-25-5103-0633
}

Citation: Mitropoulou, G.;

Oreopoulou, A.; Papavassilopoulou, E.; Vamvakias, M.; Panas, P.; Fragias, S.; Kourkoutas, Y. Origanum vulgare ssp. hirtum Essential Oil as a Natural Intrinsic Hurdle against Common Spoilage and Pathogenic Microbes of Concern in Tomato Juice. Appl. Microbiol. 2021, 1, 1-10. https://doi.org/10.3390/ applmicrobiol1010001

Academic Editor: Peter M. Muriana

Received: 13 January 2021

Accepted: 5 February 2021

Published: 20 February 2021

Publisher's Note: MDPI stays neutral with regard to jurisdictional claims in published maps and institutional affiliations.

Copyright: (C) 2021 by the authors Licensee MDPI, Basel, Switzerland. This article is an open access article distributed under the terms and conditions of the Creative Commons Attribution (CC BY) license (https:/ / creativecommons.org/licenses/by/ $4.0 /)$.

\begin{abstract}
The aim of the present study was to assess the commercial potential of the Origanum vulgare ssp. hirtum essential oil (OEO) as a natural intrinsic hurdle against common spoilage and pathogenic microbes in tomato juice. The main volatile compounds of the OEO identified by gas chromatography mass spectrometry (GC/MS) analysis were thymol and carvacrol, accounting for approximately $48 \%$ and $27 \%$, respectively. Its activity against common food spoilage and pathogenic microbes was confirmed and the minimum inhibitory concentration (MIC), non-inhibitory concentration (NIC), and minimum lethal concentration (MLC) values were determined. OEO effectiveness was further validated in commercial tomato juice. Supplementation of tomato juice with OEO at concentrations lower than the MIC (350 ppm) resulted in significant delay of food spoilage and extension of the product's shelf-life, as well as in inhibition of Listeria monocytogenes, Clostridium difficile, Saccharomyces cerevisiae, and Aspergillus niger growth after deliberate inoculation in both room and refrigerated temperatures. In conclusion, the results suggested that OEO may be used as an efficient intrinsic inhibitor of food spoilage and growth of pathogenic microbes in tomato juice.
\end{abstract}

Keywords: food spoilage; pathogens; Origanum essential oil; tomato juice; biopreservatives; antimicrobials; hurdles

\section{Introduction}

Currently, there is a strong debate regarding the safety aspects of chemical preservatives added widely in most manufactured foods to prevent the growth of spoilage and pathogenic microbes. Hence, an increased interest in essential oils from various plant origins as alternative antimicrobial natural supplements to harmful synthetic additives is occurring [1,2].

The antimicrobial activity of essential oils isolated from plants of the Lamiaceae family has been well established [3-5]. Among the Lamiaceae herbs, Origanum vulgare ssp. hirtum, commonly known as oregano, is wildly grown and also cultivated in Mediterranean countries, and the essential oil has been previously tested for its antimicrobial properties [6,7]. However, the effectiveness of the oil may vary, depending on when the plant is harvested, the cultivar, and environmental and climate factors, etc. [6,8]. Its properties are basically attributed to the main constituents of the essential oil, thymol and carvacrol [9].

A properly designed strategy for incorporation of essential oils into foods (formulation strategies, efficiency, and organoleptic quality issues) is a key factor in the development of novel products. Their insertion into a food matrix is considered an additional inherent 
factor for the growth prevention of pathogens or delay of spoilage onset. In this context, several attempts have been focused on the successful addition of essential oils and plant extracts on various foods $[10,11]$, but only a very limited number of products are available in the market, mainly due to incompatibility with food taste, ineffectiveness owing to interaction of bioactive substances with food components, and intense aroma [12].

Tomato juice spoilage and pathogenicity is mainly due to growth and activity of several microbial species, including, among others, Listeria monocytogenes, Saccharomyces sp., and Aspergillus niger $[13,14]$. L. monocytogenes is a tenacious microorganism that is ubiquitous in the environment. This Gram-positive opportunistic bacterium is of very high public health concern, as it is the cause of a life-threatening disease called listeriosis [14]. Saccharomyces sp. are unicellular microorganisms that are frequently involved in food spoilage, especially beverages and processed fruit juices [15]. A. niger is a fungus capable of producing ochratoxin, which is considered a potent hazard to human health [16]. Additionally, incidences of Clostridium difficile infection have been increased lately, as different food types may act as vectors for $C$. difficile strains. Considering that $C$. difficile spores are able to survive at temperatures up to $85^{\circ} \mathrm{C}$ and thus the pasteurization process, it is not unreasonable to suggest $C$. difficle as a "foodborne pathogen" [17,18].

The aim of the present study was to assess the industrial potential of $O$. vulgare ssp. hirtum essential oil (OEO) as a natural intrinsic hurdle against common spoilage and pathogenic microbes in tomato juice. Data suggesting extension of the product's self-life and repression of microbial growth after deliberate inoculation are presented.

\section{Materials and Methods}

\subsection{Extraction of OEO by Hydrodistillation}

Dried leaves of OEO were obtained from the Institute of Plant Breeding and Genetic Resources (Hellenic Agricultural Organization-DEMETER, Athens, Greece). The plant was collected during the maximum blooming period from regions of North Greece, dried, and screened by hand. A voucher sample of the material has been kept at the Laboratory of Organic Synthesis of the Vioryl Chemical and Agricultural Industry, Research S.A. (Vioryl). Hydrodistillation took place at Vioryl facilities in Eleonas, Thiva, Greece, in an own-constructed apparatus. The dried leaves $(9.6 \mathrm{~kg})$ were mixed with $150 \mathrm{~L}$ water into a glass enamel vessel (400 L), equipped with mechanical stirring and a two-stage glass condenser. Saturated steam of 2 bars was introduced into the vessel. After hydrodistillation for $16 \mathrm{~h}$, the resulting essential oil (OEO) was separated from water, dried over anhydrous sodium sulfate, and stored at $4{ }^{\circ} \mathrm{C}$ (412 $\mathrm{g}$ OEO was isolated, yield $\left.4.29 \%\right)$.

\subsection{Microbial Strains}

Listeria monocytogenes NCTC 10527 (serotype 4b) and Clostridium difficile (kindly provided by the Laboratoty of Clinical Microbiology of Sismanoglio Hospital, Athens, Greece), Saccharomyces cerevisiae uvaferm NEM (Lallemand, Montreal, QC, Canada), and Aspergillus niger 19111 (kindly provided by Prof. G.J.E Nychas, Agricultural University of Athens) were used in the present study.

Both bacterial strains were grown in brain heart infusion (BHI) broth (LabM, Heywood, UK) at $37^{\circ} \mathrm{C}$ for $24 \mathrm{~h}$, whereas YPD broth (yeast extract $10 \mathrm{~g} / \mathrm{L}$, peptone $20 \mathrm{~g} / \mathrm{L}$, and dextrose $20 \mathrm{~g} / \mathrm{L}$ ) or malt extract agar (LabM) were used for the growth of S. cerevisiae or A. niger at $28^{\circ} \mathrm{C}$ for 3 days or at $37^{\circ} \mathrm{C}$ for 7 days, respectively.

\subsection{OEO Emulsion Preparation}

Water emulsions containing OEO were prepared by stirring the 2 phases (water phase (79.645\% $w / w): 0.25 \% w / w$ citric acid, $10.0 \% w / w$ Quillaia extract (Ingredion Inc., Westchester, IL, USA); oil phase (20.355\% w/w): 10\% w/w OEO, 0.005\% w/w tocopherol mix (Biotecnologías Aplicadas, S.L. Madrid, Spain)) at $5000 \mathrm{rpm}$ for $20 \mathrm{~min}$ followed by homogenization using an APV-2000 homogenizer (SPX Flow Technology Rosista GmbH, Unna, Germany) as follows: first phase 50 bar, second phase 280 bar. For comparison, 
emulsions containing medium-chain triglycerides (Sternchemie, Hamburg, Germany) instead of OEO were also prepared and used as controls.

\subsection{Tomato Juice Supplementation with OEO}

The OEO emulsion was added in commercial tomato juice with no preservatives (Pummarò Passata, Unilever) in order to achieve a final concentration of $350 \mathrm{ppm}$. For comparison reasons, tomato juice containing emulsions with medium-chain triglycerides instead of OEO were also prepared and used as controls. The $\mathrm{pH}$ of the tomato juice samples was approximately 4.90. The mixtures were homogenized at $8000 \mathrm{rpm}$ for $15 \mathrm{~min}$, pasteurized at $90^{\circ} \mathrm{C}$ for $30 \mathrm{~min}$, and then either stored in glass containers at room or low temperature $\left(4^{\circ} \mathrm{C}\right)$ or deliberately spiked with spoilage or pathogenic microorganisms, as described below in Section of Antimicrobial Activity of OEO in Tomato Juice.

\subsection{Analytical Procedures \\ 2.5.1. GC/MS Analysis}

Gas chromatography mass spectrometry (GC/MS) analysis was carried out by a GC/MS system (GC: 6890A, Agilent Technologies, USA; MSD: 5973, Agilent Technologies, Santa Clara, CA, USA) using a Factor Four VF $1 \mathrm{~ms}$ column $(25 \mathrm{~m}, 0.2 \mathrm{~mm}$ i.d., $0.33 \mu \mathrm{m}$ film thickness, Agilent Technologies), as described recently [19]. Identification was carried out by comparing the retention times and mass spectra of volatiles to Willey/NIST05 and in-house-created libraries using authentic compounds (kindly provided by Vioryl) and by determining linear retention indexes (LRI) and comparing them with those reported in the literature (Nist Mass Spectral Search Program for the NIST/EPA/NIH EI and NIST Tandem Mass Spectral Library, Version 2.3, build 4 May 2017).

\subsubsection{Antimicrobial Assays}

Screening of OEO Antimicrobial Activity by the Disc Diffusion Assay

The antibacterial activity of the OEO was initially tested using the disk diffusion assay using BHI agar plates, as described previously [19]. Gentamycin (10 $\mu \mathrm{g})$ (Oxoid Ltd, Hampshire, UK) and metronidazole ( $5 \mu \mathrm{g})$ (Oxoid) were used as positive inhibitory controls for L. monocytogenes and C. difficile, respectively, whereas sterile water was used as negative control [19].

The same procedure was also followed for screening the activity against $S$. cerevisiae and $A$. niger using YPD and malt agar plates, respectively [19]. Voriconazole $(1 \mu \mathrm{g})$ (BioRad Laboratories Inc., Hercules, CA, USA) and sterile water were used as positive inhibitory and negative controls, respectively [19].

Determination of Minimum Inhibitory Concentration (MIC), Non-Inhibitory Concentration (NIC), and Minimum Lethal Concentration (MLC)

Determination of minimum inhibitory (MIC) and non-inhibitory (NIC) concentrations was carried out as recently described $[19,20]$. Briefly, BHI broths supplemented with various $\mathrm{OEO}$ concentrations (ranging from 22 to $4628 \mathrm{mg} / \mathrm{L}$ ) were inoculated with L. monocytogenes or C. difficile and incubated at $37^{\circ} \mathrm{C}$ for $24 \mathrm{~h}$. Changes in optical density were monitored using a microplate reader (Molecular Devices, VERSAmax, Hayward, CA, USA, Softmaxprov.5.0 software). BHI broths supplemented with gentamycin (ranging from 2 to $20 \mathrm{mg} / \mathrm{L}$ ) and metronidazole (ranging from 0.012 to $8 \mathrm{mg} / \mathrm{L}$ ) were used as positive inhibitory controls for L. monocytogenes and C. difficile, respectively. BHI broths with no inoculum and inoculated $\mathrm{BHI}$ broths with no OEO were used as negative controls [19]. The calculation of MIC and NIC values was based on the Lambert-Pearson model (LPM) [21,22].

As the LPM model was not applicable to S. cerevisiae and A. niger due to yeast cell sedimentation and conidia flotation, the standard protocols described by The European Committee on Antimicrobial Susceptibility Testing (EUCAST) were applied for MIC determination [23,24], using voriconazole (ranging from 0.12 to $4 \mathrm{mg} / \mathrm{L}$ ) as positive inhibitory control $[25,26]$. 
Minimum lethal concentration (MLC) was defined as the lowest concentration, resulting in a negative subculture or presence of only 1 colony-forming unit after incubation (99.9\% of the inoculum was killed). It was determined by subculturing $100 \mu \mathrm{L}$ from each well at which no growth was observed onto BHI (for L. monocytogenes and C. difficile) and YPD or malt (for S. cerevisiae or A. niger) agar plates [19].

Antimicrobial Activity of OEO in Tomato Juice

Spoilage of tomato juice supplemented with OEO or without OEO both at room temperature $\left(18-20{ }^{\circ} \mathrm{C}\right)$ and $4{ }^{\circ} \mathrm{C}$ was monitored by determining bacteria on $\mathrm{BHI}$ agar $(\mathrm{LabM})$ and yeast/mold counts on malt extract agar (LabM) after media incubation at 37 or $30{ }^{\circ} \mathrm{C}$, respectively, for $2-5$ days. Cell counts below 1 log colony forming units $/ \mathrm{mL}$ were determined by pour plating $1 \mathrm{~mL}$ of undiluted tomato juice directly to the culture medium. Of note, all juices were pasteurized prior treatments, as described above.

Both tomato juice containing $\mathrm{OEO}$ and tomato juice without $\mathrm{OEO}$ were also deliberately inoculated with $L$. monocytogenes $\left(10^{4} \mathrm{cfu} / \mathrm{mL}\right), C$. difficile $\left(10^{4} \mathrm{cfu} / \mathrm{mL}\right)$, S. cerevisiae $\left(10^{4} \mathrm{cfu} / \mathrm{mL}\right)$, or $A$. niger (100 spores $\left./ \mathrm{mL}\right)$, separately, and microbial counts were monitored both at room temperature $\left(18-20^{\circ} \mathrm{C}\right)$ and $4{ }^{\circ} \mathrm{C}$. At various intervals, samples were collected to monitor the levels of the inoculated strains. L. monocytogenes or $C$. difficile counts were measured in BHI agar (LabM) and further verified in Palcam agar (LABM) supplemented with Palcam Listeria selective supplement (LABM) or C. difficile agar (Oxoid) with selective supplement (Oxoid) and egg yolk emulsion (Oxoid), respectively, after incubation at $37{ }^{\circ} \mathrm{C}$ for $24-48 \mathrm{~h}$ (anaerobic conditions provided by Genbox atmospheric generators (BioMerieux, Athens, Greece) were applied for $C$. difficile). S. cerevisiae counts were determined in YPD agar after incubation at $28{ }^{\circ} \mathrm{C}$ for 3 days. Numbers of $A$. niger spores $/ \mathrm{mL}$ were determined by microscopic enumeration with a cell-counting hematocytometer (Neubauer chamber).

\subsection{Preliminary Sensory Evaluation and Spoilage Determination}

To determine the optimum amount of OEO that leads to acceptable organoleptic characteristics, we conducted preliminary sensory analysis of tomato juice samples by 11 not trained consumers using locally approved protocols.

Spoilage was determined macroscopically and by sensory tests. Specifically, the following scoring scale was applied: (i) class 1 for products corresponding to high quality with no off odors or off flavors, (ii) class 2 for products corresponding to slight off odors or off flavors but still acceptable, and (iii) class 3 for products corresponding to unacceptable quality. Estimation of the shelf-life limit was based on definition of the time point at which $50 \%$ of the panelists rejected the tomato juice samples.

\subsection{Statistical Analysis}

All experiments were performed in 4 replicates and the mean values are presented.

Fig. P.2.1 software (Fig.P Software Incorporated, Hamilton, ON, Canada) was used to calculate standard deviation for MIC and NIC values.

The results were analyzed with analysis of variance (ANOVA) using Duncan's multiple range test to determine significant differences $(p<0.05)$ among results (coefficients, ANOVA tables, and significance $(p<0.05)$ were computed using Statistica v.10.0).

\section{Results and Discussion}

\subsection{GC/MS Analysis of OEO}

GC/MS analysis provided data about the percentage content of the volatile compounds and not their actual concentration. In total, 51 compounds were identified (Table 1). The main compounds detected were thymol and carvacrol, accounting for approximately $48 \%$ and $27 \%$ of the total area, respectively. 
Table 1. Gas chromatography mass spectrometry (GC/MS) analysis of Origanum vulgare ssp. hirtum essential oil (OEO).

\begin{tabular}{|c|c|c|}
\hline LRI $^{1}$ & Compounds & $\%$ Area $^{2}$ \\
\hline 595 & ethyl acetate & 0.010 \\
\hline 741 & methyl isovalerate & 0.047 \\
\hline 743 & methyl-2-methyl-butyrate & $\operatorname{Tr}$ \\
\hline 820 & methyl tiglate & 0.022 \\
\hline 821 & cis-3-hexenol & $\operatorname{Tr}$ \\
\hline 852 & ethyl isobutylketone & 0.015 \\
\hline 919 & thujene & 0.250 \\
\hline 926 & $\alpha$-pinene & 0.263 \\
\hline 937 & camphene & 0.058 \\
\hline 959 & oct-1-en-3-ol & 0.607 \\
\hline 975 & myrcene & 1.026 \\
\hline 988 & $a$-phellandrene & 0.125 \\
\hline 994 & unknown alkane $\left(\mathrm{C}_{n} \mathrm{H}_{2 n+2}\right)$ & 0.026 \\
\hline 996 & $\delta$-3-carene & 0.053 \\
\hline 1001 & $a$-terpinene & 1.103 \\
\hline 1005 & p-cymene & 6.502 \\
\hline 1012 & $\beta$-phellandrene & 0.132 \\
\hline 1013 & limonene & 0.172 \\
\hline 1020 & cis-ocimene & 0.022 \\
\hline 1032 & trans-ocimene & 0.053 \\
\hline 1045 & $\gamma$-terpinene & 9.014 \\
\hline 1048 & cis-sabinene hydrate & 0.065 \\
\hline 1059 & unknown & 0.120 \\
\hline 1075 & terpinolene & 0.079 \\
\hline 1082 & linalol & 0.129 \\
\hline 1097 & unknown alkane $\left(\mathrm{C}_{n} \mathrm{H}_{2 n+2}\right)$ & 0.024 \\
\hline 1115 & unknown & 0.130 \\
\hline 1147 & borneol & 0.260 \\
\hline 1158 & terpin-4-ol & 0.316 \\
\hline 1169 & $\alpha$-terpineol & 0.100 \\
\hline 1194 & unknown alkane $\left(\mathrm{C}_{n} \mathrm{H}_{2 n+2}\right)$ & 0.087 \\
\hline 1212 & citronellol & 0.101 \\
\hline 1213 & thymyl methyl ether & 0.033 \\
\hline 1256 & citronellyl formiate & 0.027 \\
\hline 1262 & indol & 0.020 \\
\hline 1283 & thymol & 48.120 \\
\hline 1294 & carvacrol & 27.190 \\
\hline 1315 & unknown & 0.150 \\
\hline 1388 & unknown alkane $\left(\mathrm{C}_{n} \mathrm{H}_{2 n+2}\right)$ & 0.032 \\
\hline 1398 & unknown alkane $\left(\mathrm{C}_{n} \mathrm{H}_{2 n+2}\right)$ & 0.059 \\
\hline 1413 & caryophellene & 1.060 \\
\hline 1423 & unknown & 0.100 \\
\hline 1433 & unknown sesquiterpene & 0.050 \\
\hline 1446 & humulene & 0.120 \\
\hline 1488 & vnknown sesquiterpene & 0.070 \\
\hline 1500 & $\beta$-bisabolene & 1.720 \\
\hline
\end{tabular}

${ }^{1}$ Linear retention indices, ${ }^{2}$ Tr: traces $(<0.010 \%)$.

\subsection{Antimicrobial Assays}

Considering that composition and thus effectiveness of essential oils depends greatly upon a number of cultivation, environmental, and climate factors $[6,27,28]$, the antimicrobial activity of OEO against spoilage and pathogenic microbes of concern for tomato juice (L. monocytogenes, C. difficile, S. cerevisiae, and A. niger) was initially confirmed by the disk diffusion method (data not shown). Subsequently, MIC, NIC, and MLC values were assessed, as their precise determination is crucial for the food industry, in order to regulate the optimum amount of the antimicrobial agent to secure microbial safety. The 
effective growth inhibition of OEO against all microorganisms tested (Table 2) was verified, although MIC, NIC, and MLC values were significantly $(p<0.05)$ higher compared to gentamycin [19], metronidazole, and voricanozole [20], which were used as positive inhibitory controls, since antibiotics have been used as food additives in the past [29]. Although the antimicrobial activity of OEO is well documented [4-7,30-32], MIC, NIC, and MLC values should be always determined, since chemical composition may vary greatly due to environmental conditions, climate, and time of harvesting [6,8].

Table 2. Minimum inhibitory concentration (MIC), non-inhibitory concentration (NIC), and minimum lethal concentration (MLC) (mg/L) of Origanum vulgare ssp. hirtum essential oil (OEO) against Listeria monocytogenes, Clostridium difficile, Saccharomyces cerevisiae, and Aspergillus niger. Gentamycin, metronidazole, and voriconazole were used as positive inhibitory controls.

\begin{tabular}{|c|c|c|c|c|c|c|c|c|c|c|c|c|}
\hline \multirow{2}{*}{$\begin{array}{l}\text { Microbial } \\
\text { Species }\end{array}$} & \multicolumn{3}{|c|}{ Essential Oil } & \multicolumn{3}{|c|}{ Metronidazole } & \multicolumn{3}{|c|}{ Gentamycin } & \multicolumn{3}{|c|}{ Voriconazole } \\
\hline & MIC & NIC & $M^{\prime} C^{a}$ & MIC & NIC & $\mathrm{MLC}^{\mathrm{a}}$ & MIC & NIC & MLC $^{a}$ & $\mathrm{MIC}^{\mathrm{a}}$ & NIC & MLC $^{a}$ \\
\hline L. monocytogenes & $1148 \pm 27$ & $528 \pm 37$ & 5738 & - & - & - & $3.121 \pm 0.002$ & $3.001 \pm 0.002$ & 16.0 & - & - & - \\
\hline C. difficile & $1314 \pm 27$ & $204 \pm 27$ & 7404 & $0.064 \pm 0.001$ & $0.032 \pm 0.001$ & 4.0 & - & - & - & - & - & - \\
\hline S. cerevisiae & $1647^{a}$ & - & 6590 & - & - & - & - & - & - & 0.25 & - & 1.00 \\
\hline A. niger & $2197^{a}$ & - & 8786 & - & - & - & - & - & - & 0.50 & & 2.00 \\
\hline
\end{tabular}

a Standard deviation ranged in zero values.

\subsection{Antimicrobial Activity in Tomato Juice Supplemented with OEO}

Primarily, the effect of OEO on the extension of the preservation time was investigated. OEO was introduced in tomato juice in an emulsion form to facilitate homogeneous dilution at a concentration (350 ppm) lower than the MIC, as higher levels resulted in sensory faults. However, at the concentration applied, no off flavors were detected according to the preliminary sensory evaluation as the choice of an emulsifier depends greatly on the properties of the component to be dissolved, the properties of the emulsifier and the food matrix, Quillaia extract, an acid-stable and effective natural emulsifier, was chosen [33] in order to achieve micelle stability and to replace synthetic surfactants usually applied in foods and beverages [34]. Citric acid was added as a stabilizer at the emulsion (0.003 ppm final concentration at the tomato juice), but at the $\mathrm{pH}$ of the juice (4.90), it is highly unlikely to have any antimicrobial effect [35].

The results are presented in Figure 1. The OEO resulted in significantly $(p<0.05)$ lower counts for bacteria and yeasts/molds compared to the control samples (without $\mathrm{OEO}$ ), suggesting an important extension of the product's shelf-life, up to $48 \mathrm{~h}$, at room temperature. Importantly, no spoilage was noted in tomato juice with OEO at $4{ }^{\circ} \mathrm{C}$.

Subsequently, the resistance of tomato juice supplemented with $\mathrm{OEO}$ against growth of pathogenic microbes was further investigated. In this vein, tomato juice containing $\mathrm{OEO}$ and tomato juice with no OEO were deliberately inoculated with L. monocytogenes, C. difficile, S. cerevisiae, or A. niger, separately, and microbial growth was monitored both at room temperature or at low temperature, specifically at $4{ }^{\circ} \mathrm{C}$ (Figure $2 \mathrm{a}-\mathrm{d}$ ). A relatively high inoculum was tested in order to investigate the effectiveness of the oil in high microbial counts. The results showed that in all cases microbial counts were significantly $(p<0.05)$ lower in tomato juice containing OEO. 


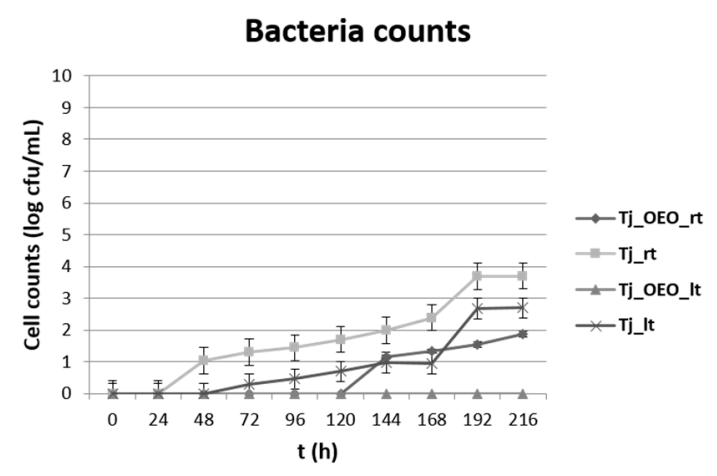

(a)

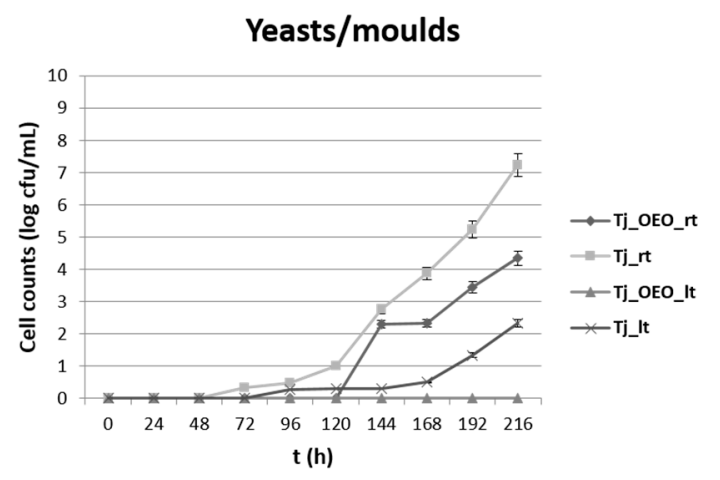

(b)

Figure 1. Effect of O. vulgare ssp. hirtum essential oil (OEO) and storage temperature on tomato juice spoilage. (a) Bacteria counts, (b) counts of yeasts/molds. Tj_OEO_rt: tomato juice containing OEO (350 ppm) stored at room temperature $\left(18-20^{\circ} \mathrm{C}\right)$; $\mathrm{Tj} \_$rt: tomato juice with no $\mathrm{OEO}$ (medium chain triglycerides were used instead) stored at room temperature $\left(18-20^{\circ} \mathrm{C}\right)$ (control); Tj_OEO_lt: tomato juice containing OEO $(350 \mathrm{ppm})$ stored at low temperature $\left(4^{\circ} \mathrm{C}\right)$; $\mathrm{Tj} \_l \mathrm{lt}$ : tomato juice with no $\mathrm{OEO}$ (medium chain triglycerides were used instead) stored at low temperature $\left(4^{\circ} \mathrm{C}\right)(\mathrm{control})$.

Supplementation of the juice with OEO at concentration lower than NIC or only slightly higher than the NIC determined for Clostridium difficile was sufficient to suppress the growth of the deliberately inoculated microbes, suggesting a clear synergistic effect of the oil and the refrigeration at $4{ }^{\circ} \mathrm{C}$. Microorganisms are very often unable to overcome the combination of several food preservation systems and hence the multiple hurdles can result in a stable and safe product without any sensory quality deterioration [36]. The use of essential oils can be thus considered an additional intrinsic determinant (hurdle) to ensure food safety, although the limitations associated to their strong smell at effective doses and the decrease in their effectiveness when added to complicated food ecosystems compared with microbiological media [37].

Several efforts on extending the preservation time of tomato juice included the use of natural volatile compounds (methyl jasmonate, ethanol, their combination, tea tree oil, and garlic oil) [38]; investigation of antimicrobial activity of food-compatible plant extracts and chitosan against naturally occurring micro-organisms in tomato juice [39]; dipping treatment in $2 \%$ ascorbic acid, citric acid, and calcium lactate solutions [40]; dipping treatment in calcium chloride and packaging in biocompostable materials or in conventional plastics [41]; and introduction of fresh-cut tomato in nisin or in nisin in combination with sodium citrate or sodium acetate solutions [17]. However, to the best of the authors' knowledge, the present study reports for the first time the effectiveness of OEO in suppressing microbial growth in deliberately spiked tomato juice. 


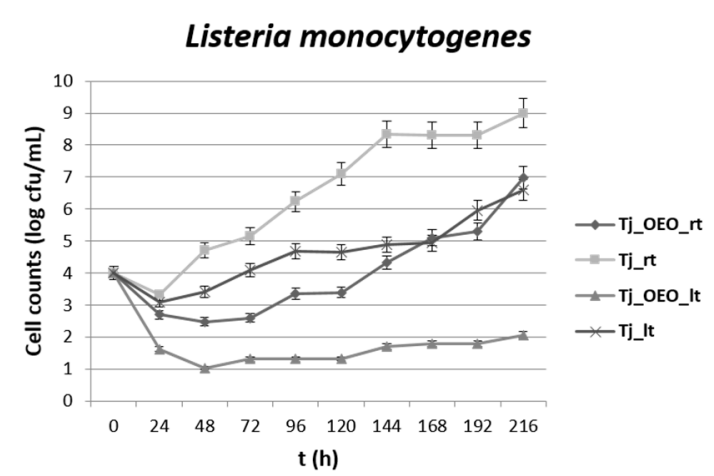

(a)

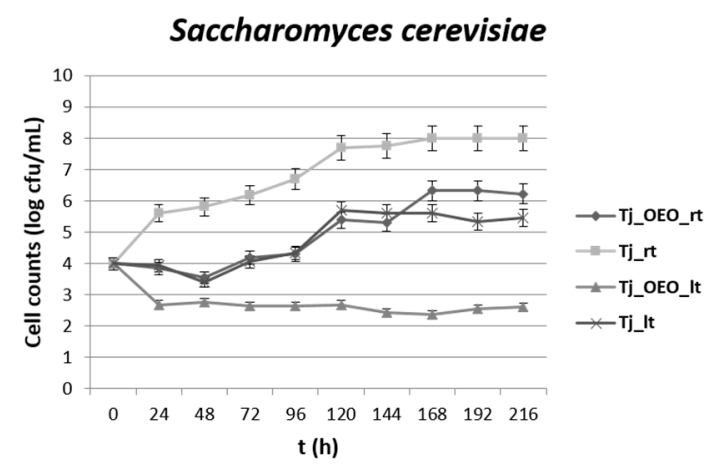

(c)

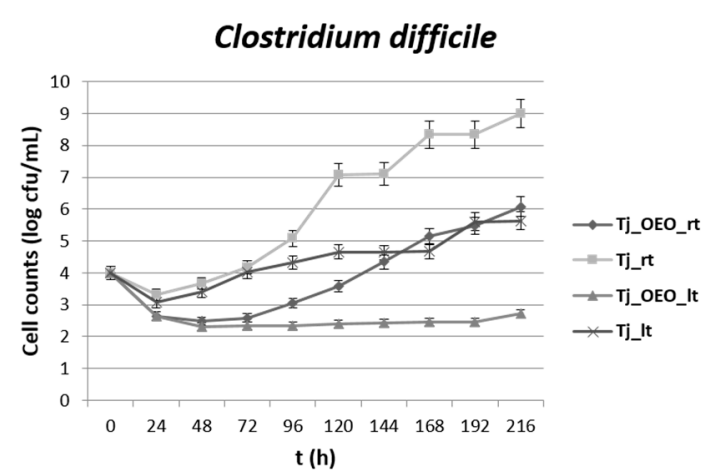

(b)

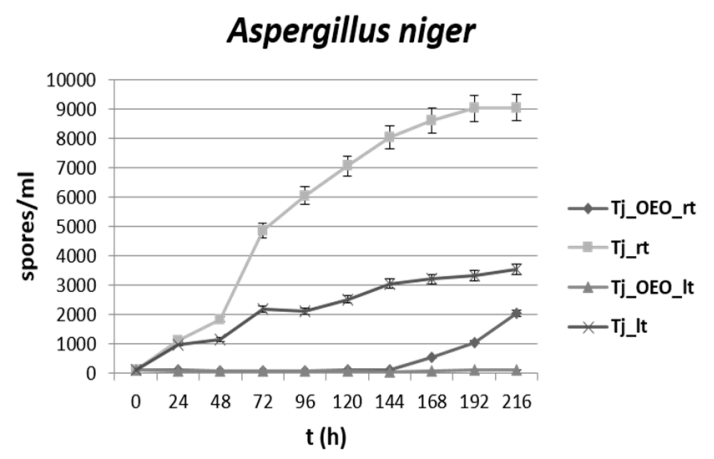

(d)

Figure 2. Effect of $O$. vulgare ssp. hirtum essential oil (OEO) and storage temperature on Listeria monocytogenes (a), Clostridium difficile (b), and Saccharomyces cerevisiae (c) counts and Aspergillus niger (d) spores in deliberately spiked tomato juice. Tj_OEO_rt: tomato juice containing OEO $(350 \mathrm{ppm})$ stored at room temperature $\left(18-20{ }^{\circ} \mathrm{C}\right)$; Tj_rt: tomato juice with no OEO (medium chain triglycerides were used instead) stored at room temperature $\left(18-20^{\circ} \mathrm{C}\right)(\mathrm{control})$; Tj_OEO_lt: tomato juice containing $\mathrm{OEO}(350 \mathrm{ppm})$ stored at low temperature $\left(4{ }^{\circ} \mathrm{C}\right)$; $\mathrm{Tj}$ _lt: tomato juice with no OEO (medium chain triglycerides were used instead) stored at low temperature $\left(4^{\circ} \mathrm{C}\right)$ (control).

\section{Conclusions}

The results revealed that OEO may be used as an efficient intrinsic inhibitor (hurdle) of food spoilage and as a protection shield against food pathogens, since fortification of tomato juice with $\mathrm{OEO}$, even at concentration below MIC, resulted in significant suppression of L. monocytogenes, $C$. difficile, $S$. cerevisiae, and A. niger growth after deliberate inoculation. Thus, its use as a biopreservative by the food industry is of utmost importance since the demand for replacement of chemical preservatives with natural alternatives is increasing.

Author Contributions: Conceptualization, Y.K.; data curation, G.M., A.O., E.P., M.V., and P.P.; formal analysis, P.P.; investigation, G.M., A.O., E.P., and M.V.; methodology, G.M.; project administration, Y.K.; resources, A.O., E.P., M.V., S.F., and Y.K.; supervision, Y.K.; validation, A.O., E.P., M.V., P.P., and S.F.; visualization, Y.K.; writing — original draft, G.M.; writing—review and editing, Y.K. All authors have read and agreed to the published version of the manuscript.

Funding: Research project co-financed by the European Union (European Regional Development Fund-ERDF) and Greek National Funds through the Operational Program “BILATERAL COOPERATION GREECE-CHINA" (project No. 12CHN_409).

Institutional Review Board Statement: Not applicable.

Informed Consent Statement: Not applicable.

Data Availability Statement: The data presented in this study are available on request from the corresponding author. 
Acknowledgments: The authors thank C. Tassou for providing full access to the Microplate Reader and N. Chorianopoulos for his valuable technical support and scientific advice.

Conflicts of Interest: The authors declare no conflict of interest.

\section{References}

1. Bakkali, F.; Averbeck, S.; Idaomar, M. Biological effects of essential oils-A review. Food Chem. Toxicol. 2008, 46, 446-475. [CrossRef] [PubMed]

2. Swamy, M.K.; Akhtar, M.S.; Sinniah, U.R. Antimicrobial Properties of Plant Essential Oils against Human Pathogens and Their Mode of Action: An Updated Review. Evid. Based Complement. Altern. Med. 2016, 2016, 1-21. [CrossRef]

3. Burt, S. Essential oils: Their antibacterial properties and potential applications in foods-A review. Int. J. Food Microbiol. 2004, 94, 223-253. [CrossRef] [PubMed]

4. Chorianopoulos, N.G.; Evergetis, E.T.; Aligiannis, N.; Mitakou, S.; Nychas, G.-J.E.; Haroutounian, S.A. Correlation between Chemical Composition of Greek Essential Oils and their Antibacterial Activity against Food-borne Pathogens. Nat. Prod. Commun. 2007, 2, 419-426. [CrossRef]

5. Nychas, G.J.E.; Skandamis, P.N.; Tassou, C. Antimicrobials from herbs and spices. In Natural Antimicrobials for the Minimal Processing of Foods; Elsevier BV: Amsterdam, The Netherlands, 2003; pp. 176-200.

6. Chorianopoulos, N.; Kalpoutzakis, E.; Aligiannis, N.; Mitaku, S.; Nychas, G.-J.; Haroutounian, S.A. Essential Oils of Satureja, Origanum, and Thymus Species: Chemical Composition and Antibacterial Activities Against Foodborne Pathogens. J. Agric. Food Chem. 2004, 52, 8261-8267. [CrossRef]

7. Şahin, F.; Güllüce, M.; Daferera, D.; Sökmen, A.; Sökmen, M.; Polissiou, M.; Agar, G.; Özer, H. Biological activities of the essential oils and methanol extract of Origanum vulgare ssp. vulgare in the Eastern Anatolia region of Turkey. Food Control. 2004, 15, 549-557. [CrossRef]

8. Baranauskienè, R.; Venskutonis, P.R.; Dambrauskienè, E.; Viškelis, P. Harvesting time influences the yield and oil composition of Origanum vulgare L. ssp. vulgare and ssp. hirtum. Ind. Crop. Prod. 2013, 49, 43-51. [CrossRef]

9. De Martino, L.; De Feo, V.; Formisano, C.; Mignola, E.; Senatore, F. Chemical Composition and Antimicrobial Activity of the Essential Oils from Three Chemotypes of Origanum vulgare L. ssp. hirtum (Link) Ietswaart Growing Wild in Campania (Southern Italy). Molecules 2009, 14, 2735-2746. [CrossRef]

10. Chorianopoulos, N.G.; Skandamis, P.N.; Nychas, G.-J.E.; Haroutounian, S.A. Agricultural University of Athens Iera odos Athens Greece Use of essential oil treatments to control the Listeria monocytogenes growth in various food commodities. Planta Med. 2008, 74, PI31. [CrossRef]

11. Tsimogiannis, D.; Choulitoudi, E.; Bimpilas, A.; Mitropoulou, G.; Kourkoutas, Y.; Oreopoulou, V. Exploitation of the biological potential of Satureja thymbra essential oil and distillation by-products. J. Appl. Res. Med. Aromat. Plants 2017, 4, 12-20. [CrossRef]

12. Hyldgaard, M.; Mygind, T.; Meyer, R.L. Essential Oils in Food Preservation: Mode of Action, Synergies, and Interactions with Food Matrix Components. Front. Microbiol. 2012, 3, 12. [CrossRef] [PubMed]

13. Oviasogie, F.E.; Ogofure, A.G.; Obatusin, S.V.; Beshiru, A.; Onwuaduegbo, J. Microbial spoilage of canned tomato sold in Benin city. J. Adv. Sci. Res. 2015, 6, 6-9.

14. Oladunjoye, A.O.; Singh, S.; Ijabadeniyi, O.A. Inactivation of Listeria monocytogenes ATCC 7644 on fresh-cut tomato using nisin in combinations with organic salts. Braz. J. Microbiol. 2016, 47, 757-763. [CrossRef]

15. Turtoi, M. Inactivation of Saccharomyces cerevisiae using nonconventional treatments. A review. Rom. Biotechnol. Lett. 2014, $19,8901-8909$.

16. Samuel, O.; Orji, M.U. Fungi Associated with the Spoilage of Post-harvest Tomato Fruits Sold in Major Markets in Awka, Nigeria. Univers. J. Microbiol. Res. 2015, 3, 11-16. [CrossRef]

17. Metcalf, D.; Costa, M.C.; Dew, W.; Weese, J. Clostridium difficile in vegetables, Canada. Lett. Appl. Microbiol. 2010, 51, 600-602. [CrossRef] [PubMed]

18. Bakri, M.M.; Brown, D.; Butcher, J.P.; Sutherland, A. Clostridium difficilein Ready-to-Eat Salads, Scotland. Emerg. Infect. Dis. 2009, 15, 817-818. [CrossRef]

19. Mitropoulou, G.; Fitsiou, E.; Spyridopoulou, K.; Tiptiri-Kourpeti, A.; Bardouki, H.; Vamvakias, M.; Panas, P.; Chlichlia, K.; Pappa, A.; Kourkoutas, Y. Citrus medica essential oil exhibits significant antimicrobial and antiproliferative activity. LWT 2017, 84, 344-352. [CrossRef]

20. Mitropoulou, G.; Sidira, M.; Skitsa, M.; Tsochantaridis, I.; Pappa, A.; Dimtsoudis, C.; Proestos, C.; Kourkoutas, Y. Assessment of the Antimicrobial, Antioxidant, and Antiproliferative Potential of Sideritis raeseri subps raeseri Essential Oil. Foods $2020,9,860$. [CrossRef] [PubMed]

21. Chorianopoulos, N.; Lambert, R.; Skandamis, P.; Evergetis, E.; Haroutounian, S.; Nychas, G.-J.E. A newly developed assay to study the minimum inhibitory concentration of Satureja spinosa essential oil. J. Appl. Microbiol. 2006, 100, 778-786. [CrossRef]

22. Lambert, R. A model for the efficacy of combined inhibitors. J. Appl. Microbiol. 2003, 95, 734-743. [CrossRef] [PubMed] 
23. Arendrup, M.C.; Meletiadis, J.; Mouton, J.W.; Lagrou, K.; Hamal, P.; Guinea, J. Subcommittee on Antifungal Susceptibility Testing (AFST) of the ESCMID European Committee for Antimicrobial Susceptibility Testing. EUCAST Definitive Document EDEF 9.3.2 Method for the Determination of Broth Dilution Minimum Inhibitory Concentrations of Anti-fungal Agents for Conidia Forming Moulds. 2020. Available online: https://www.eucast.org/fileadmin/src/media/PDFs/EUCAST_files/AFST/Files/EUCAST_ E_Def_9.3.2_Mould_testing_definitive_revised_2020 (accessed on 7 April 2020).

24. Arendrup, M.C.; Meletiadis, J.; Mouton, J.W.; Lagrou, K.; Hamal, P.; Guinea, J. Subcommittee on Antifungal Susceptibil-ity Testing (AFST) of the ESCMID European Committee for Antimicrobial Susceptibility Testing. EUCAST Definitive Document EDEF 7.3.2 Method for the Determination of Broth Dilution Minimum Inhibitory Concentrations of Anti-fungal Agents for Yeasts. 2020. Available online: https://www.eucast.org/fileadmin/src/media/PDFs/EUCAST_files/AFST/Files/EUCAST_E_Def_7. 3.2_Yeast_testing_definitive_revised_2020 (accessed on 8 April 2020).

25. Balkan, C.; Ercan, I.; Isik, E.; Akdeniz, E.S.; Balcioglu, O.; Kodedová, M.; Zimmermannová, O.; Dundar, M.; Sychrová, H.; Koc, A. Genomewide Elucidation of Drug Resistance Mechanisms for Systemically Used Antifungal Drugs Amphotericin B, Caspofungin, and Voriconazole in the Budding Yeast. Antimicrob. Agents Chemother. 2019, 63. [CrossRef]

26. Mandras, N.; Roana, J.; Scalas, D.; Fucale, G.; Allizond, V.; Banche, G.; Barbui, A.; Vigni, N.L.; A Newell, V.; Cuffini, A.M.; et al. In vitro antifungal activity of fluconazole and voriconazole against non-Candida yeasts and yeast-like fungi clinical isolates. New Microbiol. 2015, 38, 583-587.

27. Aboukhalid, K.; Al Faiz, C.; Douaik, A.; Bakha, M.; Kursa, K.; Agacka-Mołdoch, M.; Machon, N.; Tomi, F.; Lamiri, A. Influence of Environmental Factors on Essential Oil Variability in Origanum compactum Benth. Growing Wild in Morocco. Chem. Biodivers. 2017, 14, e1700158. [CrossRef]

28. Shams, M.; Esfahan, S.Z.; Esfahan, E.Z.; Dashtaki, H.N.; Dursun, A.; Yildirim, E. Effects of Climatic Factors on the Quantity of Essential Oil and Dry Matter Yield of Coriander (Coriandrum sativum L.). Indian J. Sci. Technol. 2016, 9, 6. [CrossRef]

29. Code of Federal Regulations (Annual Edition) AE 2.106/3:9/ Title 9-Animals and Animal Products. Chapter I-Animal and Plant Health Inspection Service, Department of Agriculture Subchapter E-Viruses, Serums, Toxins, and Analogous Products; Organisms and Vectors Part 114-Production Requirements for Biological Products. Section 114.10-Antibiotics as Preservatives. 9 CFR § 114.10. 1 January 2011, 39 FR 16869, May 10, 1974, as Amended at 56 FR 66784; U.S. Government Publishing Office: Washington, DC, USA, 1991.

30. Barbosa, L.N.; Rall, V.L.M.; Fernandes, A.A.H.; Ushimaru, P.I.; Probst, I.D.S.; Júnior, A.F. Essential Oils Against Foodborne Pathogens and Spoilage Bacteria in Minced Meat. Foodborne Pathog. Dis. 2009, 6, 725-728. [CrossRef] [PubMed]

31. Chami, F.; Chami, N.; Bennis, S.; Bouchikhi, T.; Remmal, A. Oregano and clove essential oils induce surface alteration of Saccharomyces cerevisiae. Phytother. Res. 2005, 19, 405-408. [CrossRef]

32. Pawar, V.C.; Thaker, V.S. In vitro efficacy of 75 essential oils against Aspergillus niger. Mycoses 2006, 49, 316-323. [CrossRef]

33. Klingenberg, A. Emulsion. US Patent 20130089644, 2013. Available online: https://patents.justia.com/inventor/andreasklingenber (accessed on 16 April 2020).

34. Yang, Y.; Leser, M.E.; Sher, A.A.; McClements, D.J. Formation and stability of emulsions using a natural small molecule surfactant: Quillaja saponin (Q-Naturale $\left.{ }^{\circledR}\right)$. Food Hydrocoll. 2013, 30, 589-596. [CrossRef]

35. Hawkins, S.G. Antimicrobial Activity of Cinnamic Acid, Citric Acid, Cinnamaldehyde, and Levulinic Acid against Foodborne Pathogens. Chancellor's Honors Program Projects. University of Tennessee, Knoxville Trace: Tennessee Research and Creative, Knoxville, TN, USA, 2014. Available online: http:/ / trace.tennessee.edu/utk_chanhonoproj (accessed on 1 May 2014).

36. Leistner, L.; Gorris, L.G. Food preservation by hurdle technology. Trends Food Sci. Technol. 1995, 6, 41-46. [CrossRef]

37. Skandamis, P.N.; Nychas, G.-J.E. Development and Evaluation of a Model Predicting the Survival of Escherichia coli O157:H7 NCTC 12900 in Homemade Eggplant Salad at Various Temperatures, pHs, and Oregano Essential Oil Concentrations. Appl. Environ. Microbiol. 2000, 66, 1646-1653. [CrossRef] [PubMed]

38. Ayala-Zavala, J.F.; Oms-Oliu, G.; Odriozola-Serrano, I.; González-Aguilar, G.A.; Alvarez-Parrilla, E.; Martín-Belloso, O. Biopreservation of fresh-cut tomatoes using natural antimicrobials. Eur. Food Res. Technol. 2007, 226, 1047-1055. [CrossRef]

39. Giner, M.J.; Vegara, S.; Funes, L.; Martí, N.; Saura, D.; Micol, V.; Valero, M. Antimicrobial activity of food-compatible plant extracts and chitosan against naturally occurring micro-organisms in tomato juice. J. Sci. Food Agric. 2012, 92, 1917-1923. [CrossRef] [PubMed]

40. Antunes, M.D.; Rodrigues, D.; Pantazis, V.; Cavaco, A.M.; Siomos, A.S.; Miguel, M.G. Nutritional quality changes of fresh-cut tomato during shelf life. Food Sci. Biotechnol. 2013, 22, 1-8. [CrossRef]

41. Patanè, C.; Malvuccio, A.; Saita, A.; Rizzarelli, P.; Rapisarda, M.; Rizzo, V.; Muratore, G. Quality aspects of fresh-cut ‘long-storage tomato' as affected by package, calcium chloride and storage time. Int. J. Food Sci. Technol. 2017, 53, 819-827. [CrossRef] 